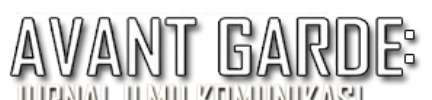

\title{
Pergulatan Diri Aktual Sebagai Pemaknaan Visual Pada Ilustrasi Efek Psikologis Body-Shaming
}

\author{
Nicodemus Koli, Rustono Farady Marta, Natasha Richie Vallerie \\ Universitas Bunda Mulia \\ Jln. Jalur Sutera Barat Kav. 7-9, Alam Sutera, Tangerang 15143, Banten \\ nkoli@bundamulia.ac.id ${ }^{1}$,rmarta@bundamulia.ac.id, natasharichiev@gmail.com
}

Submitted: 21 Oktober 2021, Revised: 15 September 2021, Accepted: 25 Oktober 2021

\begin{abstract}
Abstrak
Penelitian ini bertujuan untuk menelisik bagaimana komunikasi media dapat mengilustrasikan korban bodyshaming. Tindakan mengkritik kondisi fisik orang lain yang lazim dikenal dengan istilah body-shaming merupakan bagian dari kehidupan sosial. Bagi pribadi yang mendapat perlakuan ini, pergulatan dalam diri pun dialami. Dalam pergulatan itu, ada hasrat yang mengkondisikan diri sesuai pencitraan masyarakat umum, di satu sisi, dan menerima dan percaya diri apa adanya, di sisi lain. Kecemasan, kewaspadaan, antisipasi serta rencana tertentu ketika berhadapan dengan berbagai stigma - yang pada umumnya bernuansa ejekan atau kritikan atas kondisi fisik, menjadi bagian dari dinamika pergulatan diri, terutama pada pribadi yang mendapat perlakuan body-shaming. Pendekatan kualitatif dengan paradigma interpretif digunakan dalam penelitian ini, serta memiliki tradisi semiotika. Penelitian ini menggunakan teknik analisis teks mengingat studi menerjemahkan makna komunikasi media. Kode hermeneutik, semantik, narasi, simbolik dan kultural akan digunakan untuk menjelajahi desain ilustrasi dalam sebuah artikel. Hasil penelitian tampak dari ilustrasi "efek-psikologis-bodyshaming" sebagai representasi dari pergulatan diri ini. Persoalan eksistensi diri baik pada pribadi yang mendapat perlakuan body-shaming maupun pelakunya yang anonimitas dari pelaku body-shaming dapat disingkap secara mendalam dari ilustrasi ini. Eksistensi diri dalam konteks ini disingkap melalui tradisi semiotika dengan fokus terhadap memetakan makna visual dan verbal yang terdapat pada desain visual.
\end{abstract}

Kata kunci: anonim, body-shaming, eksistensi, komunikasi visual, semiotika

\section{Actual Self Struggle: Visual Meaning in Illustration of Body-Shaming Psychological Effects}

\begin{abstract}
The research aims to interpret how media communication are capable of representing body-shaming impacts their victims through the use of illustration. The "efek-psikologis-body-shaming" illustrates how self conflict the victim suffered from body-shaming. Criticizing other's physique or body-shaming is a part of social interaction. During this process, Individual's are experiencing physical and psychological anxiety. This anxiety keeps growing as the victim takes more negative commentary from the public. During this dillema, there are two different approaches to adjust one's physique to the public, whether they accept and cope with it or they simply turn anxious towards any stigma, such as mockery or criticism towards body-shaming. The qualitative research uses interpretive paradigm with the support of semiotics tradition. The study also uses content analysis in order to identify the meaning of the illustration of body-shaming potrayed by "efek-psikologis-body-shaming". This identification of body-shaming is analyzed through the use of hermeneutic code, such as symbolic, narrative, semantic and cultural. It is discovered in the research that the "efek-psikologis-body-shaming"illustration represents body-shaming 's self conflict. The victim's self existence and anonymous' behavior is potrayed deeply within the illustration. Self existence in this context is analyzed through semiotics of visual communication which focuses on verbal and visual meaning.
\end{abstract}

Keywords: anonym, body-shaming, existence, semiotics, visual communication 


\section{PENDAHULUAN}

Memiliki postur dan bentuk tubuh atau kondisi fisik yang ideal, menarik sesuai pandangan masyarakat umum adalah salah satu kebanggaan setiap orang, terlebih kaum wanita. Fisik ideal bagi kaum wanita dikondisikan dengan stereotip, antara lain, tinggi dan berat badan proporsional, kulit putih, langsing, hidung mancung, dan seterusnya. Tentang stereotip pada kaum wanita, Lestari (2019) menulis model fisik wanita yang ideal terdapat pada rambut yang lurus dan panjang, mata yang lentik, bibir merah dan tubuh yang tinggi dan langsing.

Inilah kurang lebih stereotip tentang cantik. Stereotip ini pun makin kuat tertanam dalam kehidupan masyarakat melalui pencitraan yang dikonstruksikan media massa. Lantas, bagaimana kondisi fisik sesesorang wanita yang tidak sesuai dengan pencitraan media? Stereotipisme terhadap kecantikan membuat wanita membenci kondisi fisiknya. Kebencian ini tumbuh dari pandangan idealisme wanita akan fisik yang baik dipandang. Dampak dari stereotipisme sendiri menciptakan karakter pemimpi dari wanita dimana identitas "cantik" telah ditanamkan kepada benak kelompok wanita tersebut.

Demikian penggalan tulisan Lestari dalam artikel yang berjudul Stereotipe Perempuan dalam Media. Kondisi tubuh seseorang - terutama wanita - tidak sesuai dengan cantik yang dicitrakan, maka kritik, pelecehan juga penghinaan pun menerpa. "Ih kamu gedutan, yah?", "eh ndut", atau "lo iteman deh, ya gak sih?", merupakan sebagian lontaran kata - kata, entah itu sebagai sapaan atau komentar biasa, namun dapat juga bermakna penghinaan (Latukolan et al., 2021). Bila lontaran itu bermakna melecehkan atau menghina, tentu kenyamanan terganggu. Kondisi seperti ini distilahkan dengan body-shaming. Metafora bahasa menjadi aspek yang penting dalam melontarkan komentar terkait fisik. Pemahaman akan makna bahasa akan membantu individu dalam memberikan komentar dan menghindari konflik verbal (Tinarbuko, 2019).

Kehidupan sosial yang diwarnai dengan pencitraan media tentang cantik mengkondisikan dan mengkonstruksikan persepsi fisik ideal kaum wanita. Dengan begitu, sadar atau tidak, body-shaming pun menghantui (Gam et al., 2020). Pelaku tindakan ini dimungkinkan dari orang-orang lingkungan terdekat, juga diri yang terintimidasi oleh pandangan orang sekitar bila berada di tempat umum. Orang-orang yang mendapat perlakuan demikian dapat menegur atau bereaksi melawan pelaku body-shaming. Namun dengan semakin berkembangnya zaman, para pelaku cenderung semakin mengkritik korban karena dianggap terbawa perasaan (Martínez-González et al., 2021).

Isu body-shaming pun tidak terlepas dari perhatian media massa. Media online www.suaramerdeka.com adalah salah satunya. Ilustrasi "efek-psikologis-body-shaming" yang ditayangkan oleh SuaraMerdeka sepintas terlihat biasa. Namun, persoalan eksistensi diri baik pada pribadi yang mendapat perlakuan body-shaming maupun pelakunya dapat disingkap secara mendalam dari ilustrasi ini. Body-shaming pun menjadi fenomena yang merisaukan dan dikaji dari berbagai perspektif.

Media online juga menyediakan sarana penyuaraan opini bagi pengguna digital. Kelompok media sosial yang terdiri dari anggota dengan pemahaman yang sejalan bersatu dalam mengekspresikan identitas kelompok mereka (Tjajadi et al., 2021). Elemen visual juga 
mendukung representasi identitas kelompok dunia virtual dimana terdapat sebuah pembangunan citra kelompok. Kelompok yang dibangun secara kolektif mengkonstruksikan citra mereka di dunia digital baik positif maupun negatif (Gandakusumah \& Marta, 2021).

Media televisi juga berperan sebagai komunikator identitas kelompok bagi khalayak. Kelompok yang terlibat kedalam penyuaraan identitas dalam televisi membangun citra mereka kepada khalayak komunikasi televisi (Fauzi \& Fasta, 2020). Televisi digital juga berkontribusi sebagai sarana ekspresi kelompok digital. Identitas kelompok ini dibangun dari berbagai unggahan video dari pencipta konten sebagai simplifikasi identitas dari kelompok (Kusumawadani et al., 2020).

Studi ini akan membahas bagaimana komunikasi visual dapat merepresentasi makna body-shaming kepada khalayak. Pemahaman khalayak akan cemoohan verbal dari fisik seseorang akan menjadi fokus dari penelitian dimana kasus body-shaming memberikan dampak psikologis yang kuat kepada korbannya (Lumampauw et al., 2020). Komunikasi visual yang terkandung dalam ilustrasi sebagai objek penelitian didasari oleh metafora visual dimana desain ilustrasi mampu menjembatani komunikasi melalui media dengan realita sosial. Negosiasi makna ini menjadi aspek utama dalam ilustrasi "Efek-Psikologi-BodyShaming" sebagai edukator visual khalayak akan urgensi body-shaming (Harry et al., 2021).

Tentunya, penelitian tentang Body-shaming bukan kali pertama dalam studi ini. Sejumlah penelitian yang telah dilakukan berupa; pertama, penelitian yang dilakukan oleh Sakinah, mengambil locus pada media sosial instagram dengan focus pada wawancara dan observasi atas 11 (sebelas) informan ini menyingkap hasil sebagai berikut; aspek citra tubuh dan penerimaan diri; bentuk body-shaming dengan cakupan verbal, atau gabungan antar verbal dengan aksi; dampak body-shaming (perasaan ingin menjadi cantik dan takut akan fisik yang tidak ideal) (Sakinah, 2018). Kedua, penelitian oleh Lestari (2019) yang mengumpulkan data melalui observasi dan wawancara ini ditemukan beberapa hal, yaitu; pelaku body-shaming terdiri dari sejumlah pihak yang dapat ditemukan didalam lingkaran sosial korban, keluarga pada khususnya. Selain itu, evaluasi dan kritik personal dari korban agar menyesuaikan fisiknya sesuai dengan postur yang ideal membuat korban menjelekkan kondisi fisiknya sendiri.

Ketiga, penelitian oleh Sri \& Astuti (2019), dimana studi dilakukan melalui pengamatan pada video youtube Rahmawati Kekeyi Putri Cantika menunjukan hasil sebagai berikut; fisik Kekeyi Putri, menggeneralisasi cantik sesuai dengan standar media, memuji yang tidak pada tempatnya, tanggapan tentang boleh dan ditidak boleh, mengungkapkan keprihatinan atas fisik seseorang. Keempat, dalam studi Trisna Sugiati mengungkapkan bahwa berdasarkan pengalaman, body-shaming terjadi dalam bentuk cacian (diatribe), sindiran (satire), ejekan (mockery), dan lelucon (jokes) (Sugiati, 2019). Terhadap bentuk serangan seperti ini, Sugiati juga menemukan bahwa ada yang pribadi yang sedih, kecewa, namun ada pula yang biasa saja.

Manfaat dari penelitian yang dilakukan akan menarasikan pergulatan pribadi yang mendapat perlakuan body-shaming ketika berhadapan dengan serangan kerumunan disingkap melalui analisis semiotika komunikasi visual pada ilustrasi "efek psikologis body-shaming" dalam penelitian ini. Bagaimana menyingkap tanda verbal dan visual untuk memahami persoalan eksistensi diri dalam body-shaming, merupakan pertanyaan penting yang akan 
ditelusuri dan pada gilirannya menunjukkan titik terang melalui interpretasi pada kode hermeneutika, simbolik, narasi, semantik, dan kebudayaan dalam bingkai komunikasi visual.

\section{METODE PENELITIAN}

Penelitian ini menggunakan pendekatan deskriptif kualitatif dalam figur komunikasi visual. Makna visual dan verbal merupakan fokus interpretasi semiotika komunikasi visual. Tanda verbal dapat diartikan sebagai gejala yang terdiri dari sejumlah faktor yang melahirkan sebuah makna dalam tulisan atau suara. Lalu, tanda verbal merujuk pada semiotika teks (bahasa). Tanda dalam bahasa umumnya diidentikkan dengan teks (Lumampauw et al., 2021). Tanda dalam bentuk teks dapat muncul sebagai gejala struktural pada tingkat mikrostruktural (dalam kalimat, sekuen) ataupun teks pada tingkatan makrostruktural (teks secara keseluruhan, wacana, antartekstualitas).

Tanda visual dapat diartikan sebagai representasi gejala dalam bentuk garis, bidang, ruang, warna, bentuk dan tekstur (Kenney, 2010). Penyingkapan tanda-tanda dan makna ini menginduk pada analisis semiotika, di mana, tanda verbal dan visual merupakan komponen pokok dalam suatu karya desain komunikasi visual baik tercetak maupun dalam media elektronik. Tanda verbal berupa kajian teks atau auditorik. Sedangkan tanda visual terungkap dalam model visual yang bergerak maupun statis (Warndana, 2017).

Untuk menyingkap makna dari tanda-tanda ini, peneliti membutuhkan kode hermeneutik, narasi, simbolik, kultural dan semantik. Kode sendiri dimengerti sebagai sistem struktural (Sya'Dian, 2015). Kode mengkomunikasikan bahasa non verbal, seperti gerak tubuh (kinesic), wajah (facial), sifat khusus manusia yang berkaitan dengan faktor alam dan lingkungan sosial (proxemic), persepsi sentuhan (tactile) dan sikap tubuh (gestural). Kode kinesic mengungkapkan gerak tubuh atau perilaku fisik seseorang diatur oleh situasi sosial tertentu. Kode ini juga menentukan citra tubuh yang dapat diterima secara sosial (Tabah Hati, 2017).

Kode facial kerap dikenal melalui "kontak mata" (eye contact) atau dikenal dengan istilah "face-as-persona" (wajah sebagai pribadi) atau komunikasi tatap muka. Wajah adalah gambaran perasaan. Kode proxemik mengatur penjagaan jarak antar manusia satu sama lain dan cara mengarahkan tubuh ketika berinteraksi dalam situasi sosial. Term proxemics diciptakan oleh Antropolog Edward T. Hall dalam kajian tentang budaya, perilaku dan aspek - aspek sosial dari jarak spasial antarindividu.

Hall mengidentifikasikan beberapa kategori jarak spasial ini, yaitu, jarak spasial intimasi (0 in. -18 in.), jarak spasial personal (1,5 ft $-4 \mathrm{ft}$ atau $0,45 \mathrm{~m}-1,21 \mathrm{~m})$, jarak spasial sosial (4 ft. - $12 \mathrm{ft}$ atau 1,21 m-3,65 m ), jarak spasial publik (12 ft. Atau 3,65m dan seterusnya). Berdasarkan definisi mengenai kode itu sendiri maka pemahaman mengenai kode hermeneutika, simbolik, narasi, semantik, dan kebudayaan pun dapat digali lebih dalam.

Kode hermeneutika mencakup sejumlah pertanyaan, teka-teki yang berujung kepada sebuah jawaban yang konkrit. Terdapat pertanyaan yang ditemukan dalam kode hermeneutik dimana jawaban yang satu melahirkan pertanyaan lainnya untuk menunda jawaban awal (Pérez-García et al., 2020). Kode hermeneutik mengandung narasi yang mempertajam isu narasi yang menciptakan sebuah misteri dibalik jawaban. Aspek provokatif dan enigma (teka - teki) yang terkandung kode hermeneutika memicu atau merangsang kita untuk 
menyingkap dan memahami makna lebih dalam (Haryono, 2019). Merujuk pada pandangan Filsuf Prancis Paul Recoeur (1913 - 2005), dalam hermeneutika, teks tidak diartikan secara sempit. Secara luas, diskursus dan tindakan patut dianggap sebagai formasi teks yang memiliki arti khusus. Sama seperti sebuah teks, percakapan dan tindakan selalu terjadi dalam konteks sejarah tertentu, melibatkan pribadi tertentu, yang mewujudkan komunikasi antar subyek (Harita et al., 2020). Karena itu, hermeneutika di sini berarti menyingkap intensi yang tersembunyi di balik teks. Memahami teks berarti merefleksikan teks dengan kehidupan nyata melalui pemaknaan yang berbeda. Dengan kata lain, refleksi terkait dengan eksistensi manusia yaitu memahami makna hidup. Percakapan dan tindakan merujuk kepada pemahaman realita yang ingin diinterpretasikan melalui teks maupun audio. Dalam arti itu, baik percakapan maupun tindakan dapat dianggap sebagai peristiwa (event) yang terjadi di tempat dan dalam waktu tertentu. Sebagai peristiwa, suatu percakapan atau tindakan selalu terjadi dalam kompleksitas relasi. Tidak ada peristiwa yang terjadi hanya dalam relasi dengan satu faktor saja. Dari perspektif relasinya, peristiwa selalu bercorak multidimensional (Grimes et al., 2020).

Semantik berarti analisis kata atau kalimat sebagai representasi dari realitas. Bila kode dimengerti sebagai komunikasi bahasa non verbal, maka kode semantik dapat dipahami dalam konteks kesesuaian antara kata atau kalimat dengan gerak tubuh (kinesic), wajah (facial), sifat khusus manusia yang berkaitan dengan faktor alam dan lingkungan sosial (proxemic), persepsi sentuhan (tactile) dan sikap tubuh (gestural). Kode semantik mengandung konotasi pada tingkatan penanda yang bersangkutan. Konotasi yang dimaksud mengacu pada maskulinitas, femininitas, kebangsaan, kesukuan, atau loyalitas. Kode ini terdiri dari isyarat, petunjuk atau kemungkinan makna yang ditawarkan oleh penanda (Lee et al., 2020).

Kode simbolik mencakup psikoanalisis, antitesis, kemenduaan, pertentangan dua unsur, atau skizofrenia dalam bentuk simbolisasi (Fensi, 2019). Pemaknaan dalam konteks ini boleh dikatakan bahwa tindakan seseorang tidak selalu merupakan ekspresi dari pikiran ataupun hasratnya. Itu berarti, kode ini tidak melahirkan makna tunggal. Ia bersifat arbitrer dan terbebas dari hegemoni interpretasi makna dari pihak tertentu. Karena itu, kode simbolik terbuka akan adanya "antitesis" atau "kontras" pada suatu teks. Dengan keterbukaan yang demikian lahirlah fragmen - fragmen makna, ketidakmungkinan makna dan makna yang kontradiktif. Kode simbolik bebas dari pemaknaan yang berorientasi pada regimentasi. Artinya, kode simbolik dapat diinterpretasi bebas sesuai segmentasi.

Kode narasi mencakup penulisan sebuah cerita, narasi maupun antinarasi (Ruslan, 2014). Kode ini dikenal juga sebagai kode tindakan yang berarti pengurutan konsep dalam sebuah cerita. Kode ini didasari oleh pemikiran proairesis, yaitu, kapabilitas seseorang untuk menentukan sebab dan akibat dari aksi yang rasional (Wijaya et al., 2021). Dalam kode narasi terdapat naratif atau anti-naratif, linear atau sirkular.

Kode kebudayaan menjadi audio yang bersifat kolektif, anonim, sub konsius, mitologi, pepatah, ilmu pengetahuan, histori, moral, psikologi, tulisan sastra, seni visual dan legenda (Hasbullah \& Yasa, 2020). Dengan kata lain, kode ini merujuk pada budaya yang bersifat material juga non material yang berupa elemen simbol, bahasa, nilai - nilai dan kepercayaan, serta norma - norma. Karena itu, kode budaya juga disebut sebagai referensial. 
Kode yang berasal dari sumber kolektif yang anonim dan otoritatif yang berkaitan dengan pengetahuan juga makna pepatah serta moralitas yang diterima bersama ini dapat ditelusuri dalam konteks kesucian, kesakralan atau baik - buruk (Rossy \& Wahid, 2016)s. Dalam kode budaya ada sisi mitologis, ideologis dan spiritual.

Kode dan makna dalam semiotika komunikasi visual dapat ditangkap dalam beberapa bentuk ekspresi, yaitu, parodi, pastiche, kitsch, camp, skizofrenik. Parodi (kata bahasa Inggris : parody) berarti suatu bentuk sindiran terhadap suatu tidakan yang dinilai buruk. Pastiche merupakan bentuk karya sastra, musik ataupun artistik yang unsur - unsurnya berasal dari berbagai sumber (Pua \& Hiramoto, 2020). Kitsch merupakan bentuk seni atau desain yang kurang mengundang selera karena gayanya yang terlalu mencolok dan prestisius (Fajri, 2020). Camp diartikan sebagai sekelompok orang yang mempunyai kesamaaan - misalnya, politik, agama, ide, gaya atau perilaku hidup. Skizofrenik (kata bahasa Inggris : Schizophrenic) berarti penderita skizofrenia - yaitu, penyakit mental di mana seseorang tidak dapat menghubungkan perasaaan dan pikiran dengan kehidupan nyata, menarik diri dari kehidupan sosial dan hidup dalam dunia imaginasinya dan mengalami delusi.

Kode, makna, dan ekspresi, dapat diadaptasikan dalam tabel berikut:

Tabel 1: Kategori Kode dalam Semiotika Roland Barthes

\begin{tabular}{|c|c|c|}
\hline Kode & Makna & Ekspresi \\
\hline Hermeneutika & $\begin{array}{l}\text { - Efek provokatif . } \\
\text { - } \quad \text { Enigma :teka - teki }\end{array}$ & - $\quad$ Parodi \\
\hline Semantik & $\begin{array}{l}\text { - Konotatif } \\
\text { - Feminin/maskulin } \\
\text { - } \text { Perversitas } \\
\text { - } \quad \text { Normal/abnormal }\end{array}$ & $\begin{array}{ll}\text { - } & \text { Pastiche } \\
\text { - } & \text { Kitsch } \\
\text { - } & \text { Camp }\end{array}$ \\
\hline Simbolik & $\begin{array}{ll}\text { - } & \text { Fragmen - fragmen makna } \\
\text { - } & \text { Ketidakmungkinan makna } \\
\text { - } & \text { Makna kontradiktif } \\
\end{array}$ & - Skizofrenik \\
\hline Proairetik & $\begin{array}{l}\text { - Naratif atau anti-naratif } \\
\text { - Linear atau sirkular }\end{array}$ & $\begin{array}{ll}\text { - } & \text { Pastiche } \\
\text { - } & \text { Kitsch } \\
\text { - } & \text { Camp } \\
\end{array}$ \\
\hline Kultural & $\begin{array}{ll}\text { - } & \text { Mitologis } \\
\text { - } & \text { Ideologis } \\
\text { - } & \text { Spiritual } \\
\end{array}$ & - Pastiche \\
\hline
\end{tabular}

\section{HASIL DAN PEMBAHASAN}

Data penelitian menunjukkan sebuah ilustrasi dari media berita SuaraMerdeka.com dimana terdapat lima figur yang berbentuk pion catur berwarna hitam serta figur wanita yang menjadi fokus sekunder dalam ilustrasi dengan ekspresi khawatir. Ilustrasi figur pion juga dilengkapi dengan sejumlah komentar yang berkaitan dengan body-shaming seperti postur tubuh, warna kulit atau kondisi wajah. Deskripsi awal dari ilustrasi menunjukkan: 


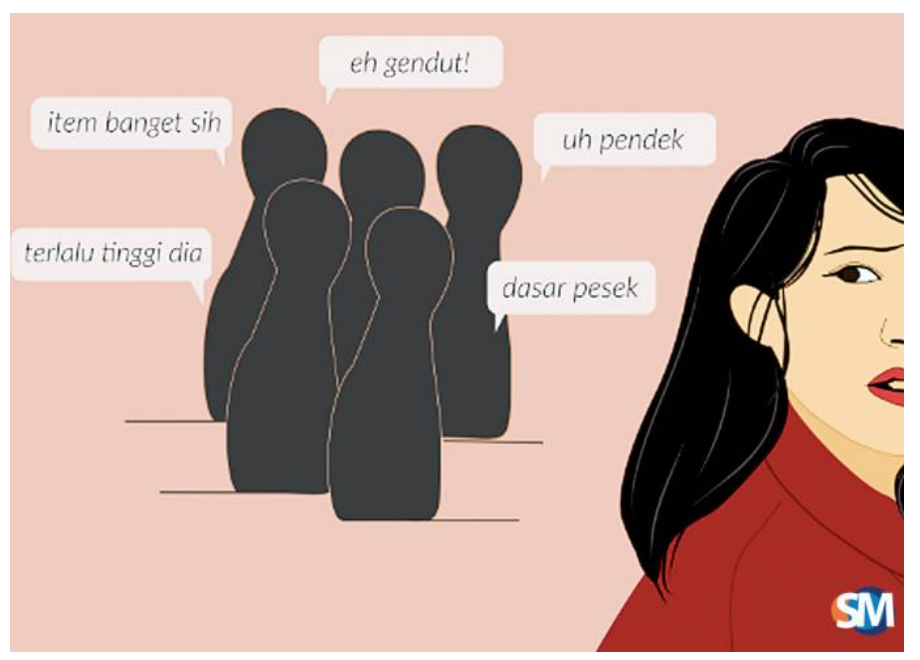

Figur 1: Ilustrasi Body-shaming (Sumber:

https://www.suaramerdeka.com/smcetak/baca/149907/efek-psikologis-body-shaming)

Ilustrasi di atas dipublikasikan suaramerdeka.com pada 2 Desember 2018 dengan menggunakan kata kunci; efek-psikologis-body-shaming. Secara visual, ilustrasi ini memperlihatkan beberapa komponen, yaitu, pertama, kata - kata (verbal). Adapun kata kata yang tertulis dalam ilustrasi ini, sebagai berikut: "eh gendut! uh pendek, dasar pesek, terlalu tinggi dia, item banget sih". Kedua, kata - kata dalam ilustrasi ini terlontar dari sketsa pion - pion catur berwana hitam. Ada 5 (lima) sketsa pion catur yang diposisikan menyatu namun tidak teratur. Ketiga, nampaknya, pada 4 (empat) di antara pion ini diarsir dengan garis horisontal. Sementara itu, pada 2 (dua) sketsa di antaranya terlihat garis batas yang menunjukkan bahwa 2 (dua) pion ini berada di depan dan 3 (tiga) lainnya yang berposisi di belakang. Keempat, sketsa manusia dengan badan dan wajah yang tidak utuh. Manusia ini disketsakan berambut hitam panjang hingga sekitar bahu, berbaju merah. Tampak, manusia ini adalah figur perempuan muda. Salah satu telinganya pun digambarkan secara tegas dan jelas. Ekspresi perempuan ini - pada mata dan alis yang digambarkan searah telinga serta posisi mulut yang sedikit terbuka - tampak sedang menangkap kata - kata dari "pion - pion". Kelima, huruf "SM" dengan latarbelakang tiga lingkaran - berwarna jingga (orange), biru muda dan biru tua. Keenam, warna merah muda (pink) sebagai latar tata letak (layout).

Dalam konteks komunikasi visual, beberapa aspek ilustrasi efek-psikologis-bodyshaming perlu didalami, yaitu, bias daya tarik (attractiveness bias), penyelarasan (allignment), perbadingan (comparison), dan errors. Pertama, bias daya tarik (attractiveness bias) menyangkut aspek fisik manusia. Dalam hal ini, suatu penilaian positif atau negatif tergantung menarik tidaknya fisik seseorang. Seseorang akan dinilai positif bila menarik secara fisik, baik itu wajah, bentuk tubuh yang bagus dan sensual, warna kulit dan seterusnya. Pertimbangan bias daya tarik dalam konteks desain relevan dengan gambar orang dalam pemasaran dan periklanan. Dalam ilustrasi efek-psikologis-body-shaming ini, figur perempuan menjadi menarik dan mengundang komentar dari figur pion - pion catur justru karena tampak fisiknya yang tidak sesuai harapan umum. Dengan demikian, kondisi seperti ini tidak relevan bila dijadikan obyek dalam pemasaran dan periklanan. Kedua, penyelarasan 
(alignment) merupakan penempatan elemen-elemen sedemikian rupa sehingga sesuai baris atau kolom yang sudah diatur baik di sisi pinggir maupun tengah. Elemen desain ilustrasi membutuhkan penyesuaian dengan sejumlah elemen lainnya yang terlibat untuk menciptakan unifikasi desain dan kohesi, yang berperan pada estetika desain secara utuh. Dalam ilustrasi efek-psikologis-body-shaming ini, figur pion tidak terlihat secara jelas warna apa yang mencolok, tidak menarik. Agar kontras, figur perempuan dilukis dengan dominan warna merah, mencolok, menarik, jelas. Elemen figur pion yang tampak lebih kecil dibuat lebih dari satu agar seimbang dengan figur perempuan yang tampak lebih besar. Lalu, garis horisontal mempertegas keberadaan figur pion yang tampak samar. Ketiga, perbandingan (comparison), yaitu, suatu metode yang mengilustrasikan hubungan dan pola perilaku dalam sistem yang terkontrol. Metode ini digunakan untuk mengidentifikasi dan merepresentasikan informasi dengan menggunakan perbadingan proporsional, setara, tolok ukur, konteks yang sama atau lazim dipakai frasa "apple to apple". Dalam ilustrasi efek-psikologis-bodyshamingini, figur 4 (empat) pion terlihat kecil, posisinya jauh. Sementara, sosok perempuan, hanya 1 (satu), lebih besar, dan dekat. Komposisi sisi kiri - kanan ilustrasi ini seimbang. Keempat, kesalahan (errors), yaitu, suatu tindakan atau kelalaian yang mengakibatkan hasil yang tidak diinginkan. Bila komposisi seimbang, maka, faktor kesalahan dalam ilustrasi ini tidak tampak.

Secara konotatif, kata - kata olokan yang diungkapkan seperti fisik yang gendut, pendek, pesek, terlalu tinggi, item banget, merepresentasikan perasaan atau emosi dalam interaksi intersubyektif mengenai realitas yang tidak diharapkan. Di balik ungkapan ini dapat diinterpretasikan bahwa fisik ideal yang diharapkan dan dikonstruksikan baik secara feminin maupun maskulin adalah langsing, tinggi, mancung, tidak terlalu tinggi, tidak begitu hitam. Lalu, makna perversitas kata - kata ini adalah melecehkan. Dengan begitu, fisik yang gendut, pendek, pesek, terlalu tinggi, item banget itu dianggap sebagai abnormal. Seiring dengan pemahaman akan makna konotatif, perversitas serta abnormal, kode semantik diekspresikan dalam pastiche, kitsch dan camp. Ekspresi pastiche terlihat dalam ilustrasi secara keseluruhan, di mana, elemen - elemen dalam ilustrasi tidak berasal dari teks atau sumber tunggal, namun, intertekstualitas. Ekspresi kitsch dapat dilihat pada warna yang dikenakan pada baju figur perempuan - merah mencolok. Ekspresi camp yang diartikan sebagai sekelompok orang yang mempunyai kesamaaan - antara lain, ide, gaya atau perilaku hidup - dapat dilihat pada figur "pion - pion" catur. Terdapat pemahaman dari kode semantik yang mengandung konotasi dari tingkatan tanda ilustrasi Body-shaming berdasarkan cuplikan berita.

Analisis semiotika merujuk pada pemaknaan. Karya komunikasi visual yang tercipta baik tercetak maupun dalam media elektronik, tanda verbal dan visual ditempatkan sebagai komponen pokok. Tanda verbal berupa tulisan teks. Sedangkan tanda visual terungkap dalam pentataan visual yang statis dan/atau mobilisasi. Kode hermeneutik, simbolik, narasi, semantik, dan kebudayaan digunakan untuk menangkap pemaknaan dari tanda tersebut. Sementara itu, kode sendiri mengkomunikasikan bahasa non - verbal, seperti gerak tubuh (kinesic), wajah (facial), sifat khusus manusia yang berkaitan dengan faktor alam dan lingkungan sosial (proxemic), persepsi sentuhan (tactile) dan sikap tubuh (gestural). 
Dalam kerangka kode hermeneutika Ilustrasi "Body-shaming" disingkap melalui artikulasi pertanyaan, teka - teki atau enigma, respons, penangguhan jawaban, akhirnya menuju jawaban. Makna teka - teki itu disimak dalam beberapa pertanyaan berikut; pertama, apa makna figur wanita yang ditampilan tidak utuh dan bahasa non - verbal, yakni, wajah (facial) dan sikap tubuhnya (gestural)? Kedua, apa makna "pion-pion" itu dan figur siapakah yang direpresentasikan dan apa tujuannya? Apa yang terjadi sehingga terungkap pernyataan - pernyataan yang bernada menghakimi? Ketiga, apa makna garis horisontal? Keempat, apa makna Huruf "SM" dengan latarbelakang tiga lingkaran - berwarna jingga (orange), biru muda dan biru tua merupakan logo media online Suaramerdeka.com? Kelima, apa makna latar belakang pink? Berikut uraian jawaban atas pertanyaan - pertanyaan ini.

Pertama, makna figur wanita yang ditampilan tidak utuh dan bahasa non - verbal, yakni, wajah (facial) dan sikap tubuhnya (gestural). Sketsa sang wanita yang tidak utuh menimbulkan enigma (teka - teki), ekspresi penuh tanda tanya. Kecemasan tampak pada tanda visual sketsa manusia ini. Dia yang disketsakan berambut hitam panjang hingga sekitar bahu, berbaju merah ini adalah figur seorang gadis. Telinganya pun digambarkan secara tegas dan jelas namun hanya terlihat satu. Ekspresi gadis ini - pada mata dan alis yang juga hanya satu digambarkan searah telinga. Posisi mulut yang sedikit terbuka dan hidung yang hanya muncul sebagian - memberi kesan sedang menangkap kata - kata dari "pion - pion". Dengan begitu makna sketsa ini dapat disingkapkan bahwa anggota tubuh yang tidak dimunculkan - sebagian wajah, mata, telinga, hidung, rambut dan mulut - menyiratkan bahwa figur perempuan ini tidak sepenuhnya cemas. Secara hermeneutika, dapat diinterpretasikan bahwa di balik kecemasan ada rencana, kewaspadaan dan antisipasi.

Kedua, makna "pion-pion" itu dan figur yang direpresentasikannya serta makna pernyataan - pernyataan yang bernada menghakimi. Teka - teki ini pun munculkan suatu kecurigaan. Teks verbal dalam ilustrasi "Body-shaming" menunjukkan momen reflektif kesadaran diri bahwa ada ketidakberesan pada kondisi fisik, khususnya untuk seorang perempuan. Gendut, pendek, pesek, terlalu tinggi, hitam (kulit hitam) merupakan kata - kata yang merepresentasikan ketidakberesan itu. Sadar atau tidak, hal ini menggiring sang perempuan untuk memulihkan fisik dan menjadi seperti gambaran ideal masyarakat pada umumnya. Artinya, pernyataan verbal dari "pion - pion" itu mensyaratkan, jika kondisi gendut maka harus dilangsingkan. Jika pendek maka harus dibuat ditinggikan. Jika pesek (hidung) maka harus dimancungkan. Jika terlalu tinggi maka harus dibuat sedikit lebih pendek. Jika kulit hitam maka harus dibuat menjadi putih. Tanda visual dalam ilustrasi sketsa "body-shaming" dilihat pada sketsa pion - pion catur berwana hitam. Ada 5 (lima) sketsa pion catur yang diposisikan menyatu namun tidak teratur. Pion - pion ini disketsakan sebagai sumber teks verbal. Sketsa yang berwarna hitam ini identik dengan gelap, suram, kabur, mencemaskan, sosok yang tidak jelas, samar - samar hanya tampak seperti "pion pion catur". Sosok yang samar - samar dan tidak dikenal itu menyatu, kompak maju menyerang, bisa serentak, bisa bertahap - ada yang di depan terlebih dahulu dan ada yang di belakang menyusul. Sosok yang samar - samar itu tidak menampilkan eksistensi dirinya yang otentik. Mereka tampil dalam bentuk kerumunan (crowd).

Ketiga, makna garis horisontal. Nampaknya, pada 4 (empat) di antara pion ini diarsir dengan garis horisontal. Pada 2 (dua) sketsa di antaranya terlihat garis batas yang 
menunjukkan bahwa 2 (dua) pion ini berada di depan dan 3 (tiga) lainnya yang berposisi di belakang. Garis horisontal dalam ilustrasi "Body-shaming" menyiratkan bahwa serangan kerumunan yang anonim itu mengarah pada figur yang kelas sosialnya sama. Serangan ini tentu mencemaskan.

Keempat, makna Huruf "SM" dengan latarbelakang tiga lingkaran - berwarna jingga (orange), biru muda dan biru tua merupakan logo media online Suaramerdeka.com. Huruf "SM" dengan latarbelakang tiga lingkaran - berwarna jingga (orange), biru muda dan biru tua merupakan logo media online Suaramerdeka.com. Dalam bingkai hermeneutika Martin Heidegger - dasein, logo ini dipahami dalam konteks menyingkap kemungkinan makna masa depan. Untuk memahami logo SM dalam arti praktis, ada 3 (tiga) hal yang dapat digarisbawahi; konsep praktis untuk memahami pra - teoritis dan pra- diskursif. Orang yang memahami sesuatu dalam arti praktis tidak perlu tahu ajaran tentang hal yang bersangkutan. Orang tersebut langsung dapat memahami tanpa mendalami ungkapan tersebut secara verbal. Memahami logo Suaramerdeka.com sebagai penanda keberadaan suatu media masa berbasis teknologi internet sebagaimana yang tampak dalam kesadaran setiap orang. Berikutnya berupa konsep praktis yang menyiratkan pemahaman akan diri sendiri. Memahami merupakan bagian dari menjadi diri sendiri. Logo Suaramerdeka.com tidak dapat dipisahkan dari Suaramerdeka.com sebagai media komunikasi - mulai dari konten, pekerja media hingga audiens atau pembaca serta unsur - unsur terkait. Konsep terakhir berupa konsep praktis untuk memahami pendahuluan konsep epistemologis yang diadopsi Dilthey sebagai metode ilmiah dalam rangka memahami secara ilmiah. Pemahaman situasi secara eksistensial menjadi aspek penting dalam analisis ini. Itu berarti, sebelum sampai pada konsep rasio dan pengalaman dalam memaknai, orang terlebih dahulu memahami dalam mengambil keputusan berdasarkan prinsip - prinsip dalam bertindak yang muncul dari keyakinan hati. Subyektivitas mendahului obyektivitas. Keberadaan logo ini menampakkan hasil dari pengambilan keputusan berdasarkan prinsip - prinsip dalam bertindak yang muncul dari keyakinan hati dari para personil yang terlibat dalam struktur internal Suaramerdeka.com.

Kelima, makna latar belakang berwarna merah muda (pink). Kemudian, latar belakang sketsa berwarna pink penting untuk dipahami juga karena berkontribusi dalam memaknai seluruh ilustrasi "Efek Psikologis Body-shaming". Dengan pink yang bernuansa cerah dapat memperlihatkan sosok yang kabur, gelap dan anonim. Artinya, sosok kerumunan pion - pion catur yang anonim itu, bahkan figur perempuan yang cemas dapat terlihat lebih jelas. Setiap sosok dikenal pada posisinya masing - masing karena dilatarbelakangi dengan pink. Dengan demikian kondisi eksistensial masing - masing figur dapat diketahui. Secara hermeneutis, makna pink mensimbolkan diri kepada khalayak tidak hanya dari segi kognitif, melainkan korelasi dengan situasi eksistensial. Kondisi ini mengantar setiap subyek untuk memahami bahwa kebenaran bukan merupakan korespondensi antara pemaknaan teks, juga bukan koherensi yang terkandung dalam teks itu sendiri, melainkan fenomena yang menyingkapi makna yang berlangsung dalam eksistensial khalayak dengan teks. Karena itu, memahami di sini - seperti dalam pemikiran Heidegger - berciri proyektif.

Masih dalam kerangka kode hermeneutika, efek provokatif yang muncul dari teka teki dalam pertanyaan dan uraian di atas adalah kecurigaan. Lalu, ekspresi dari makna dalam kode hermeneutika adalah parodi yang dapat dilihat dalam kecemasan figur perempuan yang 
terbawa arus persepsi umum mengenai fisik yang ideal di satu sisi, dan figur pion - pion yang tidak tampil sebagai pribadi yang bertanggung jawab atas diri sendiri, sebaliknya tampil dalam kerumunan (crowd), di sisi lain.

Seperti uraian pada deskripsi data, kata - kata yang nampak dalam ilustrasi "Efek Psikologis Body-shaming" - "eh gendut! uh pendek, dasar pesek, terlalu tinggi dia, item banget sih" - yang perlu dianalisis sebagai representasi dari realitas. Secara konotatif, kata kata yang diungkapkan seperti ini merepresentasikan perasaan atau emosi dalam interaksi intersubyektif mengenai realitas yang tidak diharapkan. Di balik ungkapan ini dapat diinterpretasikan bahwa fisik ideal yang diharapkan dan dikonstruksikan baik secara feminin maupun maskulin adalah langsing, tinggi, mancung, tidak terlalu tinggi, tidak begitu hitam. Lalu, makna perversitas. Kata - kata ini adalah bentuk pelecehan. Dengan begitu, fisik yang gendut, pendek, pesek, terlalu tinggi, item banget itu dianggap sebagai abnormal. Seiring dengan pemahaman akan makna konotatif, perversitas serta abnormal, kode semantik diekspresikan dalam pastiche, kitsch dan camp. Ekspresi pastiche terlihat dalam ilustrasi secara keseluruhan, di mana, elemen - elemen dalam ilustrasi tidak berasal dari teks atau sumber tunggal, namun, intertekstualitas. Ekspresi kitsch dapat dilihat pada warna yang dikenakan pada baju figur perempuan - merah mencolok. Ekspresi camp yang diartikan sebagai sekelompok orang yang mempunyai kesamaaan - antara lain, ide, gaya atau perilaku hidup - dapat dilihat pada figur "pion - pion" catur. Pemahaman akan kode semantik dapat dicapai berdasarkan analisis ini.

Kode simbolik mencakup penandaan dari segi psikoanalisis, antitesis, dualisme, pertentangan dua persona, atau skizofrenia. Kode simbolik menawarkan "kontras" atau "antitesis" pada sebuah teks. Kode ini juga dikenal sebagai kode pengelompokan atau simbol yang mudah dikenal, berulang secara sistematis melalui berbagai cara dan sarana tekstual. Fragmen - fragmen makna merujuk pada tanda verbal dan visual. Tanda verbal dapat disimak pada ungkapan verbal ;"eh gendut! uh pendek, dasar pesek, terlalu tinggi dia, item banget sih". Sementara itu tanda visual dapat disimak pada; pertama, sketsa figur wanita yang ditampilan tidak utuh dengan bahasa non - verbalnya. Kedua, sketsa "pion-pion" yang anonim. Ketiga, garis horisontal yang disambung dengan figur pion. Keempat, huruf "SM" dengan latarbelakang tiga lingkaran - berwarna jingga (orange), biru muda dan biru tua merupakan logo media online Suaramerdeka.com. Kelima, latar belakang pink. Dari unsur unsur dalam fragmen makna dapat disingkap makna kontradiktif. Kondisi fisik yang tidak diharapkan; "eh gendut! uh pendek, dasar pesek, terlalu tinggi dia, item banget sih" bermakna kontradiktif fisik ideal yang diharapkan dan dikonstruksikan, terutama, secara feminin, yaitu, langsing, tinggi, mancung, tidak terlalu tinggi, tidak begitu hitam. Figur perempuan bermakna kontradiktif dengan figur laki - laki (pion). Figur "pion" yang tampak dalam kerumunan, anonim bermakna kontradiktif dengan individu yang tampak jelas. Sisi terang dan jelas pada latar belakang (pink) bermakna kontradiktif dengan sisi gelap dan kabur pada setiap unsur ilustrasi. Garis horisontal bermakna kontradiktif dengan vertikal. Makna kode simbolik tampak dalam ekspresi skizofrenik yang dapat disimak pada konteks pernyataan yang bersifat melecehkan dalam tanda verbal yang muncul dari figur anonim yang hanya hidup dalam dunia imaginasinya. Kemudian, skizofrenik juga dapat disingkap dalam 
kecemasan pada figur perempuan yang tampak menarik diri dari kehidupan sosial sebagai akibat tanda verbal yang melecehkan dari figur anonim.

Kode narasi mengandung sebuah cerita, narasi atau antinarasi. Kode ini dikenal sebagai kode tindakan atau narasi, artinya sekuensial dalam tindakan atau cerita. Kode ini didasarkan atas konsep proairesis, yaitu, kapabilitas untuk menentukan tuaian dari tindakan yang rasional. Lalu, ekspresi yang dapat diketahuai dari makna kode ini berupa pastiche, kitsch, camp. Secara naratif cerita dapat dimulai dari sudut pandang figur perempuan. Ia tampil mencolok - baju merah dan tampak berbibir merah mencolok di suatu hari yang cerah. Penampilan ini menarik perhatian pihak lain. Dari posisi agak jauh beberapa sosok yang tampak kurang jelas memperhatikannya. Sembari menilai, terlontarlah ungkapan verbal; "eh gendut! uh pendek, dasar pesek, terlalu tinggi dia, item banget sih". Ungkapan - ungkapan ini mengundang reaksi figur perempuan. Secara non - verbal terlihat ekspresi perempuan ini - pada mata dan alis yang digambarkan searah telinga serta posisi mulut yang sedikit terbuka - tampak sedang menangkap kata - kata dari beberapa sosok itu. Nampaknya ia cemas. Dari narasi ini, makna yang dapat ditangkap adalah pola komunikasi sirkular, di mana, tanda visual dan non verbal bermula dari sosok perempuan yang mengarah ke sosok anonim. Lalu sosok anonim melancarkan serangan verbal kepada sosok perempuan dan kemudian ada reaksi non verbal dari sosok perempuan. Lalu, seperti uraian ekspresi makna kode semantik, dalam kode narasi ini pun pastiche nampak dalam intertekstualitas. Lalu, Kitsch dapat terlihat pada warna yang dikenakan pada baju dan bibir figur perempuan - merah mencolok. Camp nampak pada figur "pion - pion" catur yang mempunyai kesamaaan ide, gaya atau perilaku hidup, yang mengungkapkan kondisi yang tidak diharapkan pada sosok perempuan.

Mengenai kode kebudayaan dalam konteks ilustrasi "Efek Psikologis Body-shaming", makna mitologis yang tersingkap adalah memiliki kondisi fisik yang gendut, pesek, terlalu pendek atau terlalu tinggi, berkulit hitam, bukanlah harapan atau keinginan setiap orang, terlebih kaum wanita. Logisnya, bila tidak diharapkan mestinya kondisi fisik seperti ini diabaikan saja. Namun sebaliknya, fisik yang demikian justru menarik perhatian dan menjadi bahan komentar orang - orang di lingkungan sekitar. Lantas, fisik yang menarik dan menjadi harapan setiap orang itu dikonstruksikan oleh siapa?

Meminjam konstruksi wancana Michel Foucault (1926 - 1984) yang didalami oleh Agustin (2009) dalam penelitiannya, paling kurang ada sebagian kondisi fisik yang dapat disingkap, yaitu terkait tanda verbal "eh gendut!" dalam ilustrasi "Efek Psikologis Bodyshaming". Berikut petikan temuan penelitiannya:

"Definisi gemuk (sinonim dengan gendut) yaitu; pertama, suatu kondisi abnormal yang tidak sesuai dengan standar masyarakat. Kedua, suatu kondisi di mana tubuh tidak sehat. Ketiga, bentuk tubuh yang tidak ideal membuat kondisi fisik tidak menarik untuk dipandang. Keempat, fenomena yang lucu untuk ditertawakan. Stereotip gemuk yang berkembang dalam masyarakat yaitu; abnormal, pola hidup yang tidak sehat, sumber penyakit, tidak atraktif hingga memiliki tingkat kecerdasan yang rendah. Adapun karakter dari wanita gemuk berupa malas, lamban, mudah kelelahan, aktifitas yang minim, memiliki tendensi konsumsi makanan yang berlebih, tidak produktif dan minder. Lantas, sikap masyarakat terhadap perempuan gemuk, yaitu, mengolok - olok, menyindir, 
mempermalukan, memandang remeh, aksi koersif untuk mengenakan pakaian berwarna gelap. Sebaliknya, stereotip dan keuntungan (bertubuh) langsing terdiri dari: mendapat pakaian sesuai ukuran, sehat, tidak dipandang sebelah mata, kebebasan dari cemoohan komunitas, cantik dan menarik.

Dengan demikian dapat dipahami, kode kebudayaan yaitu aspek auditorik yang bersifat kolektif, anonim, terlahir sub konsius, mitos, kebijaksanaan, pengetahuan, sejarah, moral, psikologi, sastra, seni dan legenda. Kode budaya juga disebut sebagai referensial karena merujuk pada realitas di masa lampau dan kini dalam berbagai cara pandang dari setiap orang, waktu dan ruang. Kode yang berasal dari suara kolektif yang anonim ini menempatkan diri sebagai figur otoritatif yang lebih mengetahui tentang postur dan kondisi fisik yang ideal bagi wanita. Suara otoritatif ini nampaknya diterima sebagai hal yang wajar dalam kehidupan sosial.

Body-shaming atau tindakan mengkritik kondisi fisik seseorang bersinggungan dengan eksistensi diri. Berhadapan dengan kritik, bahkan pelecehan atas kondisi fisik, eksistensi diri dapat diinterpretasikan sebagai pergulatan menjadi diri sendiri. Eksistensi diri dipahami sebagai keberadaan diri aktual. Dalam bahasa Latin, eksistensi berasal dari kata existere yang diartikan sebagai muncul, ada, timbul dan memiliki keberadaan aktual - dari kata ex (keluar) dan sistere (tampil, muncul). Dalam konteks body-shaming, keberadaan diri aktual berhadapan kondisi fisik yang menjadi harapan. Keberadaan aktual tersingkap ketika manusia membuat pilihan dan komitmen. Artinya, dalam setiap situasi dan kondisi orang harus memilih cara hidup di dunia. Orang memilih cara berada - dalam - dunia, demikian Kierkegaard (1813 - 1855), Filsuf Eksistensialis. Memilih dan berkomitmen mengkondisikan ruang batin seseorang menjadi medan berbagai gagasan dan perundingan. Bila, seseorang berhasil mengambil keputusan, maka dasar dan prinsip dalam bertindak terlahir dari keyakinan hati secara pribadi. Oleh Kierkegaard, kondisi ini disebut "subyektivitas", bukan subyektivisme. Mengapa? Dalam subyektivisme, hal yang dipikirkan atau diungkapkan sekedar mencakup persoalan rasa (a matter of taste) yang mengandung relativisme. Dengan begitu, orang tidak memiliki relasi dengan dunia di luar dirinya. Sehingga konsep tanggung jawab tidak ada di dalam paham ini. Sementara itu dalam subyektivitas, manusia berelasi dengan sesuatu yang melampaui diri sendiri terhadap dunia luar. Dunia luar di sini terdiri dari manusia lain maupun Yang Ilahi. Relasi dengan sesuatu yang berada di luar dirinya itu merupakan ciri hakiki subyektivitas manusia. Relasi dengan dunia luar ini menjadi konkret ketika manusia menggunakan kebebasan dan memeluk kebenaran secara pribadi. Di dalamnya, ada tugas (task) dan tanggung jawab (responsibility), bukan rasa (taste). Karena itu, dalam subyektivitas - menurut Kierkegaard - eksistensi otentik dapat dicapai. Cara berada yang otentik berarti dalam hidup ada keselarasan antara kehidupan batin dan penampilan lahiriah di publik. Orang tidak lagi mengangkangi dua kehidupan, di mana, penampilan lahiriah seseorang berbeda, bahkan bertolak belakang dengan kehidupan batiniahnya. Orang tidak lagi hidup dalam kepalsuan karena setiap keputusan diambil secara pribadi dan bebas dengan penuh kesadaran dan hasrat serta komitmen. Itulah cara mengada manusia sebagai keberadaan aktual.

Dalam keberadaan aktual, eksistensi sejati berarti bertarung menghadapi perlawanan, dan mengalami hasrat yang membuktikan keberadaan. Berada secara sungguh (to truly exist) 
berarti membuat keputusan sendiri dan bukan sekedar ikut arus (Atabik, 2016). Individu harus mengidentifikasi diri dengan keputusan yang konkrit dalam rangka menjalani kehidupan yang unik. Proses ini akan membangun pendirian individu yang mengalami sejumlah pergulatan pilihan dalam hidup. Eksistensi diri tidak tampil begitu saja dalam individu, komitmen harus dibutuhkan baik dari segi fisik dan batin untuk hadir ditengah kerumunan. Individu juga harus memiliki pengetahuan tentang makna dari kehidupan manusia yang luas untuk menemukan tujuan hidup yang patut mereka jalani. Memperjuangkan eksistensi otentik memerlukan keberanian untuk melawan segala bentuk kepalsuan hidup. Hidup secara sungguh - sungguh mengartikan perjuangan, bukan hanya sekedar hidup dalam lingkaran sistem nilai dan rutinitas massa.

Dalam bentangan perjuangan, cara mengada manusia tidaklah instan, namun berlangsung dalam proses. Oleh karena mengada dalam keselarasan antara kehidupan batiniah dan lahiriah sebagai pribadi, maka individu akan berusaha untuk keluar dari arus opini publik yang menghantui mereka. Semua individu teridentifikasi sebagai anggota komunitas, bukan sebagai kepribadian mereka sendiri. Identitas pribadi individu dapat pudar dalam proses ini dan mereka dapat larut kedalam perkumpulan yang diikuti. Dalam kerumunan orang cenderung mengikuti arus dan kehendak massa. Lalu, kondisi yang ada dalam kerumunan itu adalah massa dengan sifat anonimitasnya. Kerumunan bertentangan dengan ide mengenai keunikan pribadi dan pandangannya pun anonim.

Dalam "efek psikologis body-shaming", figur anonim direpresentasikan oleh "pion pion". Dalam kerumunan, "pion - pion" ini tidak tampil sebagai individu yang mandiri, sehingga bertentangan dengan ide mengenai keunikan pribadi. Sangatlah jelas bahwa "pion pion" di sini bukan berperan sebagai individu, melainkan sebuah kelompok dengan kesatuan pikiran. Kepribadian mereka juga melebur dengan identitas kelompok yang lebih dominan. Bila ada ungkapan verbal massa seperti yang diungkapkan sosok samar - samar, pion catur, sangat mungkin sosok anonim lain mengikuti. Karena itu, setiap pribadi dituntut untuk berani melawan arus, demikian menurut Kierkegaard (Brogaard et al., 2020). Lantas, garis horisontal dalam ilustrasi "Body-shaming" menyiratkan bahwa serangan kerumunan yang anonim itu mengarah pada figur yang kelas sosialnya sama. Serangan ini tentu mencemaskan karena berasal dari pihak yang tak dikenal, namun mengganggu ekstistensi diri pihak yang diserang, yaitu figur perempuan yang bergulat dalam pertentangan antara keberadaan aktualnya ketika berhadapan dengan pandangan anonim.

Eksistensi diri yang dimaskud di sini adalah keberadaan manusia sebagai subyek yang tak tergantikan. Setiap subyek itu unik. Eksistensi sebagai keberadaan aktual manusia tersingkap ketika manusia membuat pilihan dan komitmen. Artinya, dalam setiap situasi dan kondisi orang harus memilih cara hidup di dunia. Orang memilih cara berada - dalam dunia, demikian Kierkegaard, Filsuf Eksistensialis. Ketika membuat pilihan, manusia merdeka. Di saat memilih, ia sendirian. Di situlah manusia dihukum untuk merdeka.

Pandangan yang berasal dari kerumunan - dalam hal ini, olok - olokan terhadap fisik seseorang yang dianggap abnormal - selalu bersifat anonim. Sumber mula pandangan itu samar, bahkan tidak dikenal. Lalu, orang banyak - kerumunan - tidak pernah bijaksana, bahkan idenya pun tak masuk akal. Penilaian kolektif yang ekstrim. Manusia, seperti yang umum dikatakan, berpikir secara kelompok. Mereka marah juga secara berkelompok, 
sementara akan reda satu demi satu perlahan - lahan. Kemarahan kolektif sebagai sesuatu yang biasa. Dalam imajinasi popular, kelompok cenderung menyebabkan orang menjadi bodoh atau gila atau keduanya, demikian papar Charles Mackay (1814 - 1889), penulis Skotlandia yang pada 1841 menerbitkan sebuah kronik hiburan Extraoridinary Popular Delusion and Madness of Crowds. Kondisi dalam kerumunan itu adalah massa dengan sifat anonimitasnya. Di sini, massa tidak pernah mencapai standar yang dimiliki anggota terbaiknya. Orang banyak bisa menjadi berani, pengecut atau kejam. Namun, orang banyak tidak pernah menjadi bijaksana. Di tengah orang banyak hanya ada kebodohan dan bukan kebijaksanaan. Orang banyak tidak pernah bertindak dengan dasar tuntutan kecerdasan yang tinggi dan mereka biasanya terdiri atas orang - orang yang kurang cerdas dan tersingkir (Yudhaswara \& Hidayat, 2021). Namun di lain sisi, pandangan anonim ini menjadi kuat karena bersifat intertekstual. Angapan abnormal Karena itu, sumber olok - olokan itu tidak dapat diidentifikasikan pada subyek tertentu.

Berikut peneliti melampirkan hasil pemetaan ilustrasi body-shaming dari SuaraMerdeka melalui analisis teks menggunakan tabel:

Tabel 2. Pemetaan Kode Analisis Teks Ilustrasi Efek Psikologis Body-shaming

\begin{tabular}{|l|l|}
\hline Kode & Deskripsi \\
\hline Hermeunetik & $\bullet$ Enigma perempuan terkait kondisi fisik \\
& $\begin{array}{l}\text { } \\
\end{array}$ \\
& Penghakiman pion terhadap fisik yang tidak ideal \\
& - Eerumunan yang menghujat fisik perempuan \\
\hline Semantik & Makna perversitas dari Body-shaming \\
\hline Simbolik & Dualisme ilustrasi perempuand dan pion yang \\
& menunjukkan skizofrenik \\
\hline Proairetik & Reaksi fisik perempuan melalui ilustrasi \\
\hline Budaya & Abnormalitas fisik mengundang perhatian masyarakat \\
\hline
\end{tabular}

Sumber: Hasil Olahan Peneliti, 2021

Hasil analisis dari ilustrasi Efek-Psikologis-Body-Shaming menunjukkan adanya dualisme dalam body-shaming yang terdapat dalam ilustrasi ini. Kode hermeunetik mengidentifikasi enigma perempuan terkait kondisi fisik yang tidak ideal melalui teknik ilustrasi yang tidak menfokuskan perempuan dalam bingkai ilustrasi. Penghakiman publik juga diilustrasikan melalui pion sebagai anggota masyarakat yang mengikuti arus penghakiman yang disertai dengan dialog negatif terkait kondisi fisik.

Dualisme body-shaming terdapat dari kode simbolik yang menunjukkan adanya kondisi skizofrenia yang disembunyikan melalui ilustrasi. Efek Psikologis Body-shaming secara tidak langsung menyenggol isu skizofrenia yang berkaitan dengan kondisi fisik perempuan yang tidak ideal dan komentar publik akan idealisme fisik perempuan. Kode simbolik mendeteksi adanya makna perversitas dari body-shaming yang mensimbolisasi ketertarikan dan fantasisasi publik akan postur tubuh perempuan yang ideal. 
Ilustrasi Efek Psikologis Body-shaming juga menarasikan reaksi perempuan terhadap komentar publik akan kondisi fisiknya. Hal tersebut didukung dengan posisi perempuan yang terpotong bingkai ilustrasi serta menghadap kebelakang pion yang menyimbolkan publik yang seakan-akan menjauhi perempuan akibat kondisi fisik seperti kotak teks disekitar pion tersebut. Konteks kultural dalam ilustrasi ini mengimplikasi abnormalitas sebagai hal yang dianggap negatif bagi masyarakat. Negatifitas kemudian dilontarkan kepada orang yang mereka anggap memiliki abnormalitas dalam kondisi fisik yang dapat berhujung kepada pengrusakan kondisi psikologis atau mental kepada korban body-shaming.

\section{SIMPULAN}

Pergulatan diri aktual terjadi ketika berhadapan dengan body-shaming dapat disingkap, antara lain, melalui pendekatan semiotika komunikasi visual dengan analisis tanda verbal dan visual yang terdapat pada ilustrasi "efek psikologis body-shaming". Seiring dengan itu, kode hermeneutik, simbolik, narasi, semantik, dan kebudayaan merupakan jalur menuju kedalaman pemahaman eksistensi diri.

Melalui kode hermeneutik tersingkap bahwa di balik kecemasan ada rencana, kewaspadaan dan antisipasi dari pribadi yang diterpa body-shaming. Sebaliknya, para pelaku tidak menampakkan diri secara otentik karena tampil dalam bentuk kerumunan (crowd). Sekaligus, peristiwa "body-shaming" menyiratkan bahwa serangan kerumunan yang anonim itu mengarah pada figur yang kelas sosialnya sama. Dalam kode semantic tersingkap bahwa peristiwa body-shaming merepresentasikan perasaan atau emosi dalam interaksi intersubyektif mengenai realitas yang tidak diharapkan. Realitas ini dianggap sebagai abnormal. Dalam kode simbolik tersingkap bahwa body-shaming mengkondisikan pribadi yang diterpa body-shaming untuk menarik diri dari kehidupan social, bahkan mengarah ke kondisi skizofrenik. Pada kode narasi tersingkap bahwa dalam body-shaming terdapat pola komunikasi sirkular - antara pribadi yang diterpa body-shaming dan para pelaku. Pada kode budaya tersingkap bahwa pelaku body-shaming merupakan suara kolektif yang anonim dan bersifat otoritatif.

\section{UCAPAN TERIMA KASIH}

Penulis mengucap syukur kepada Tuhan atas berkatNya yang berlimpah yang senantiasa menyertai penulis dalam merampungkan artikel ini. Penyampaian terima kasih juga kepada Direktorat Penelitian, Pengembangan, dan Pengabdian kepada Masyarakat (P3M) Universitas Bunda Mulia yang menyediakan jalur pengembangan intelektual melalui ragam fasilitasi penelitian ilmiah. Juga tak kalah penting, media www.suaramerdeka.com yang menyediakan sumber informasi data sebagai salah satu inspirasi penelitian ini. Terima kasih kami sampaikan juga kepada pihak Pengelola Jurnal Avant Garde di bawah naungan Fakultas Ilmu Komunikasi Universitas Budi Luhur, atas kesempatan yang diberikan untuk mendiseminasikan hasil riset ini, utamanya kepada penelaah ahli yang telah memberikan masukan untuk memperbaiki artikel ini.

\section{DAFTAR PUSTAKA}

Agustin, S. (2009). Foucault Dan Komunikasi (Telaah Konstruksi Wacana Dan Kuasa 
Foucault Dalam Lingkup Ilmu Komunikasi). Jurnal Ilmu Komunikasi UPNYK, 7(3), 103061.

Atabik, A. (2016). Percampuran Budaya Jawa dan Cina: Harmoni dan Toleransi Beragama Masyarakat Lasem. Sabda: Jurnal Kajian Kebudayaan, 11(1), 1. https://doi.org/10.14710/sabda.v11i1.13215

Brogaard, B., Chomanski, B., \& Gatzia, D. E. (2020). Consciousness and information integration. Synthese. https://doi.org/10.1007/s11229-020-02613-3

Fajri, N. C. (2020). Dualisme citra sedulur sikep dalam film dokumenter: analisis film "samin vs semen" dan "sikep samin semen." MEDIASI - Jurnal Kajian Dan Terapan Media, Bahasa, Komunikasi, 1(2), 124-135. https://doi.org/https://doi.org/10.46961/mediasi.v1i2.40

Fauzi, E. P., \& Fasta, F. (2020). Modern Muslimah in Media : A Study of Reception Analysis in " Saliha " Program on NET TV. ASPIRATION, 1(November), 135-162. http://www.aspiration.id/index.php/asp/article/view/19/28

Fensi, F. (2019). Paradoxic Language "Cebong-Kampret" in Facebook as a Mirror of The Political Language of Indonesia. Bricolage: Jurnal Magister Ilmu Komunikasi. https://doi.org/10.30813/bricolage.v5i02.1887

Gam, R. T., Singh, S. K., Manar, M., Kar, S. K., \& Gupta, A. (2020). Body-shaming among school-going adolescents: prevalence and predictors. International Journal of Community Medicine And Public Health, 7(4), 1324. https://doi.org/10.18203/23946040.ijcmph20201075

Gandakusumah, B., \& Marta, R. F. (2021). Visualisasi Elemen Pembentuk Consumer Brandscape Melalui Oposisi Biner Semiotika Pemasaran Xing Fu Tang (幸福堂) Dan Xi Bo $\mathrm{Ba}$ (喜悦). Jurnal Bahasa Rupa, 4(2), 167-176. https://doi.org/10.31598/bahasarupa.v4i2.808

Grimes, C. A., Khokhar, D., Bolton, K. A., Trieu, K., Potter, J., Davidson, C., Dunford, E. K., Jan, S., Woodward, M., \& Bolam, B. (2020). Salt-Related Knowledge, Attitudes and Behaviors (KABs) among Victorian Adults Following 22-Months of a Consumer Awareness Campaign. Nutrients, 12(5), 1216.

Harita, F. M., Sadono, T. P., Sya, M., Fernando, J., \& Goswami, J. K. (2020). Traveloka as the Ultimate Workplace for Millenial Graduates in Information and Technology. ASPIRATION Journal, 1(November), 163-181.

Harry, H., Marta, R. F., \& Briandana, R. (2021). Memetakan Tautan Budaya Lasem melalui Dokumenter Net . Biro Jawa Tengah dan MetroTVNews. ProTVF, 5(2), 227-246. https://doi.org/https://doi.org/10.24198/ptvf.v5i2.33411

Haryono, C. G. (2019). Genealogi Wacana Pada Pesan Agitatif Pidato Prabowo Subiyanto Tentang Nkri Bubar Tahun 2030. Bricolage: Jurnal Magister Ilmu Komunikasi, 5(01), 030. https://doi.org/10.30813/bricolage.v5i01.1740

Hasbullah, H., \& Yasa, G. P. P. A. (2020). Makna Kode Visual Dalam Scene Film Animasi “ Battle of Surabaya." Jurnal Bahasa Rupa, 3(2), 124-129. https://doi.org/10.31598/bahasarupa.v3i2.460

Kenney, K. (2010). Visual communication research designs. Routledge. 
Kusumawadani, V., Santoso, N. R., \& Herawati, D. M. (2020). Youtube As a Media Expression of Transgender Women. ASPIRATION Journal, 1(May), 95-112. http://www.aspiration.id/index.php/asp/article/view/8

Latukolan, J. J., Marta, R. F., \& Engliana, E. (2021). When Words Matter: Language Choices and Brand Building on Two Global Coffee Shop Retail Brands in Indonesia. Budapest International Research and Critics Institute (BIRCI-Journal): Humanities and Social Sciences, 4(2), 2899-2906. https://doi.org/10.33258/birci.v4i2.1974

Lee, Y. L., Jung, M., Nathan, R. J., \& Chung, J.-E. (2020). Cross-National Study on the Perception of the Korean Wave and Cultural Hybridity in Indonesia and Malaysia Using $\begin{array}{llll}\text { Discourse on Social Media. Sustainability, } & \text { 12(15), } 6072 .\end{array}$ https://doi.org/10.3390/su12156072

Lestari, S. (2019). Bullying or Body-shaming? Young Women in Patient Body Dysmorphic $\begin{array}{lllll}\text { Disorder. PHILANTHROPY: Journal of Psychology, } & 3(1), \quad 59 .\end{array}$ https://doi.org/10.26623/philanthropy.v3i1.1512

Lumampauw, A., Lestari, R., Marta, R. F., \& Fernando, J. (2020). Awakening Revealed through Rose's Visual Analysis on \#LangkahHijau Commercial Ads. Avant Garde, 8(2), 121. https://doi.org/10.36080/ag.v8i2.1231

Lumampauw, A., Marta, R. F., Nugroho, Y., Sandel, T. L., \& Lie, S. (2021). The art of honing the conscience through bukalapak ads: barongsai Indonesia, juara hati membangun bangsa. International Journal of Visual and Performing Arts, 3(1), 9-21. https://doi.org/https://doi.org/10.31763/viperarts.v3i1.342

Martínez-González, M. B., Pérez-Pedraza, D. C., Alfaro-Álvarez, J., Reyes-Cervantes, C., González-Malabet, M., \& Clemente-Suárez, V. J. (2021). Women Facing Psychological Abuse: How Do They Respond to Maternal Identity Humiliation and Body-shaming? International Journal of Environmental Research and Public Health, 18(12), 6627. https://doi.org/10.3390/ijerph18126627

Pérez-García, E., Ortega-Galán, Á. M., Ibáñez-Masero, O., Ramos-Pichardo, J. D., Fernández-Leyva, A., \& Ruiz-Fernández, M. D. (2020). Qualitative study on the causes and consequences of compassion fatigue from the perspective of nurses. International Journal of Mental Health Nursing, 10. https://doi.org/10.1111/inm.12807

Pua, P., \& Hiramoto, M. (2020). White hot heroes: Semiotics of race and sexuality in Hollywood ninja films. Language and Communication. https://doi.org/10.1016/j.langcom.2020.02.003

Rossy, A. E., \& Wahid, U. (2016). Analisi Isi Kekerasan Seksual Dalam Pemberitaan Media Online Detik.Com. Jurnal Komunikasi.

Ruslan, A. (2014). Struktur Narasi Media Game "Warcraft 3: Reign of Chaos" Studi Pada Media Seni Kontemporer. Avant Garde, 2(2), 60-78.

Sakinah. (2018). Citra Tubuh, Dampak dan Cara Mengatasinya. Jurnal Emik, 1(1).

Sri, Y., \& Astuti, W. (2019). Body-shaming di Dunia Maya: Studi Netnografi pada Akun Youtube Rahmawati Kekeyi Putri Cantika Body-shaming in The Virtual: Netnographic Study on Youtube Accounts Rahmawati Kekeyi Putri Cantika. Universitas, 5(1), 166188. http://journal.uta45jakarta.ac.id/index.php/kom/article/view/1624

Sugiati, T. (2019). The influence of body-shaming toward FISIP Airlangga University 
students behaviour pattern. Indonesian Journal of Social Sciences, 11(02), 16-24.

Sya'Dian, T. (2015). Analisis Semiotika Pada Film Laskar Pelangi. Jurnal Proporsi, 1, 5163.

Tabah Hati, S. (2017). Model Pendidikan Karakter yang Baik di Sekolah Alam. IJTIMAIYAH Jurnal Ilmu Sosial Dan Budaya, 1-32.

Tinarbuko, S. (2019). Membaca Makna Iklan Politik Pilpres 2019. Mudra Jurnal Seni Budaya. https://doi.org/10.31091/mudra.v34i2.707

Tjajadi, O. P., Marta, R. F., \& Engliana, E. (2021). Women's Resistance on Instagram Account @singlemomsindonesia. JHSS Journal of Humanities and Social Studies, 5(2), 111-115. https://doi.org/https://doi.org/10.33751/jhss.v5i2.3710

Warndana, R. A. P. (2017). Semiotika Logo Video Game The Last Story. DeKaVe, 8(2). https://doi.org/10.24821/dkv.v8i2.1635

Wijaya, B. S. S., Kurniawan, L. S. M. W., Marta, R. F., Dimyati, D., \& Hidayat, E. (2021). Menarasikan Pencak Silat pada Iklan Marjan 2011 dan 2018 dari Perspektif Chatman. Interaksi: Jurnal Ilmu Komunikasi, 9(2), 130-140. https://doi.org/10.14710/interaksi.9.2.130-140

Yudhaswara, R. K., \& Hidayat, D. (2021). Deskripsi Pengalaman Perilaku Selektif Memilih Informasi Di Masa Pandemi Covid-19 Pada Media Massa Televisi Description of Selective Behavioral Experience of Choosing Covid-19Information in Mass Media Television. Jurnal Penelitian Komunikasi Dan Opini Publik, 25(1), 61-73. 